\title{
Translating productively: texts, contexts and concepts
}

\author{
Nina Gribat* \\ Sheffield Hallam University
}

\begin{abstract}
Summary
This paper examines the role of language and translation in social science research with a focus on methodological issues. So far, these have received relatively little attention in publications on social science methodologies as well as in lively languagerelated debates in human geography journals of recent years. The lack of methodological concern is surprising, as there seems to be an increasing interest in international and comparative research and practice. However, the literature suggests that in order to draw out the political implications of translation, which are otherwise glossed over, it needs to go beyond transferring text from source language to target language as a seamless reproduction of the original. Like this, it becomes an issue of methodological concern. I therefore suggest approaching translation as a productive open-ended process that pays close attention to specificities of contexts and concepts and makes cultural difference visible throughout the research process. This approach aims at decentring taken-for-granted assumptions about the clarity of meaning in the source as well as in the target language. In reviewing the existing literature on issues of language, power and translation this paper builds on my experiences of doing a PhD as a foreign student in England.
\end{abstract}

Keywords: methodology; language; translation.

Languages are not strangers to one another, but are, a priori and apart from all historical relationships, interrelated in what they want to express (Benjamin, 1970: 73).

\section{Introduction}

In recent years, academia is becoming increasingly international. This is certainly the case in the UK and German context, of which I have first-hand experience. In the UK, numbers of foreign students at universities are rising (BBC News, 2008). Almost 30 per cent of all PhD students in the UK are foreign students (Paasi, 2005). In addition, many UK universities have 'internationalisation strategies', which do not only aim at continuing to attract foreign students, but also at fostering international research. In Germany, a growing number of courses are taught in English, of which the German 
Academic Exchange Service awards the top ten MA degrees. In addition, academic staff are ever more encouraged to publish in international journals. To support this there are several funding opportunities from German institutions aimed at fostering international publications, which by-and-large means publications in English. Literature on these issues suggests that similar tendencies of internationalisation can be found in other countries and language contexts too.

In this development, two aspects seem to go hand in hand: English is becoming a more proliferative language - often equated with being the international language. At the same time it is increasingly confronted with other languages, not least in the form of growing numbers of non-native speakers becoming or aspiring to become part of the international (English-language) research world. This may suggest that concerns with language, and moreover translation, should become pertinent, not least in a methodological sense.

A review of journal articles in human geography and planning that deal with issues of language shows two broad fields of interest connected to language: language and power; and language and translation. The first issue, what I call 'language and power', subsumes the part of the debate that is concerned with Anglo-American hegemony in a so-called 'international' research and publication environment (Minca, 2000; Moss et al., 2002; Samers and Sidaway, 2000; Gutiérrez and López-Nieva, 2001; Paasi, 2005; Desbiens and Ruddick, 2006). The focus of this part of the debate lies on publication practices as well as on the access of foreign language speakers to the international research world, which is generally equated with being an English language research world. The second issue deals with more practical concerns of 'language and translation' (Sidaway et al., 2004; Temple, 1997; Temple and Young, 2004; Müller, 2007). Here, the main emphasis lies on translation practices and the problems and possibilities thereof.

Two aspects surprise me in this context: on one side far fewer human geography or planning articles deal with the more practical concerns of researching in a multilanguage context; on the other side relatively few connections are made between the two parts of the debate. My aim in this article is to address these issues in exploring both sides of the debate and making connections between them. A special interest in methodological implications allows me to focus on the very practical facets of this exploration that are often neglected in favour of the seemingly bigger issues of linguistic dominance. However, as I will show, a concern for the very practical aspects may be the first step to de-stabilise this seemingly cemented power relation.

A particular interest in methodological implications is supported by a number of additional observations. In the literature on methodology and methods, language and translation are of little priority and in social science PhD research training they are of no particular focus. Even though most UK universities offer vital and important support in terms of language 'skills' in the form of English classes for foreign students and foreign language classes for students with a research interest abroad, these classes seldom grasp the more complex issues connected to language and translation because of being non-subject-specific. Yet, the more complicated issues of language and translation come to the foreground as soon as one sees (or accepts) the world as consisting of specific, situated contexts and concepts such as much of qualitative social science research does. Seen in this way, language adds another layer to areas of knowledge production where knowledge is conceived of as situated, acknowledging that 'the sort of knowledge made depends on who its makers are' (Rose, 1997: 306-7). In this context, language and translation are more than technical issues. They call for another layer of reflection on one's positionality. To view them with a similar reflexivity as one might view gender, race and sexuality may provide an interesting avenue. 
Literature on feminist and post-colonial methodologies can offer useful starting points, even though it rarely addresses language and translation directly.

This paper is based on my experiences as a foreign student in a PhD programme at a UK university where I am based in an Urban and Regional Studies research group hence the focus on human geography and planning literature. My case study is in my home country, Germany, which means all my empirical material is in German, whereas most of the theoretical texts I work with are in English, including a variety of translated works of foreign language authors such as Foucault. As I came to realise, my research practice is based on an ongoing effort of translation to make both areas speak to each other. Taken-for-granted, implicit understandings of the context and of concepts lose their points of reference when taken into a different language context. However, a new and different understanding may be gained in these encounters. I want to emphasise this productive, enriching experience while working with different languages.

The paper is structured in two distinct but interrelated sections dealing with methodological considerations in terms of language and power and in terms of language and translation. Using examples from my own research two issues that play a role in translation - contexts and concepts - will help me in discussing this.

\section{Methodological concerns with language and power}

The debate on what I have called 'language and power' touches on a range of issues. One of its starting points is the use of English as the new lingua franca (Minca, 2000; Aalbers, 2004; Kitchin, 2005; Paasi 2005; Desbiens and Ruddick 2006), as the international academic language. This raises certain questions in terms of linguistic dominance and 'linguistic homogenisation' (Short, et al., 2001) or, in different words, 'Anglo-American hegemony' in social science research in general and human geography specifically. One of the main arguments in this debate is that academic publishing in human geography is not as 'international' as it pretends to be (Short et al., 2001; Paasi, 2005; Gutierrez and López-Nieva, 2001), with most of the authors and referees of articles in international journals being English-native speakers or at least based at Anglo-American universities. The limitation of access of non-native English speakers to this seemingly international academic world is in turn problematised. Non-native speakers may feel left behind because of language issues both in terms of publication practices in international (English language) journals, but also at international (English language) conferences (Belina, 2005; Desbiens and Ruddick, 2006). Such exclusions may take place based on linguistic or organisational issues such as who is invited to be a referee for articles (see above), who can partake in the lively discussions at conferences and which theoretical background is expected of contributors in both contexts.

Two issues of methodological concern can be derived from this discussion: the perceived hierarchy of languages; and the emphasis of specific empirical and theoretical worlds. In relation to the first issue, that languages can be perceived in certain hierarchical orders, Temple and Young state:

It is not only words that may be value-laden, but languages also. The perspective of one language-using community on another is rarely neutral and the perceived status of languages rarely equivalent. Such differences in power between languages also influence the translation of meaning. The way researchers represent people who speak other languages is influenced by the way they see their social world (2004: 167). 
These hierarchies can be met with resistance, as Temple and Young demonstrate for British Sign Language (BSL) users in relation to English speakers. In an interview, this can turn the perceived power relation on its head.

From my experience, there is another aspect that can be added to this discussion. Speaking the same language does not mean that issues of power are obsolete. My case study is located in a small town in East Germany. Being a native German speaker, it might at first look like the issue of the perceived status of languages does not count in this case. I am not looking at a linguistic 'other', I am not going 'out there', but at the same time not really 'back here' either (see also Mandiyanike, 2009). This is because I was born and grew up in West Germany and a division between Easterners and Westerners (in German colloquially called Ossies and Wessies) still remains. In this context, Kollmorgen speaks of a 'discursive contempt' of East German socio-cultures (2007). How much this experience of being rendered subaltern by Westerners is 'lived' became clear in my interviews as the issue of where I was from, East or West, was raised by most of my interviewees. Issues of power are at work whether language is shared or not and, as feminist and post-colonial contributions to methodology have shown, one's own position within these relations needs to be reflected upon even though this endeavour (of achieving full reflexivity) is always limited (Rose 1997). Yet, as Temple and Young state, it is important to face these challenges not least to gradually dismantle them:

Boundaries around languages are permeable. Although the conversation with people who use other languages is difficult, it is possible, and probably essential, if we are to move on from the objectifying gaze on difference (Temple and Young, 2004: 174).

The second issue that the debates on language and power bring up is that of the particularity of theoretical and empirical worlds and certain gaps between different (language) worlds. The different scholarly tradition of people from other language contexts (Garcia-Ramon, 2003) is seen as a factor preventing them accessing international (English) journals. It has been contended that this emphasis on different scholarly traditions may be seen as an attempt to evoke distinct homogeneous linguistic and theoretical spaces fitting neatly with national contexts. Samers and Sidaway, for instance maintain:

Whatever 'national' scales, traces, or traditions of influence might operate in human geography [or planning research], these are already inextricably tangledup with other contexts... we need to appreciate more fully the inherent hybrid (or if you prefer, the transnational) quality of all geographical traditions (2000: 665$6)$.

And indeed, concepts are not necessarily bound to one language context, sometimes they cross different language contexts. Amongst these, Gemeinschaft and Gesellschaft (Tönnies, 1940) are but one example of theoretical notions of foreign origin that have developed a rich tradition in the social sciences in the Anglo-American world in the last decades. In addition, 'territorial cohesion', a term of French origin, arose in connection with the European Union context of (spatial) policy making and research (Faludi, 2004). Similarly, the notions 'social inclusion' and 'social exclusion', also of French origin, made their way into the English policy discourse via the EU research and policy context.

Such examples of concepts that cross language contexts also question the perception of a homogeneous international (Anglo-American) research world, often conceptualised as the 'core', and several 'peripheral' non-English research worlds (see 
Paasi, 2005). However, despite these forms of exchange I still want to make the case for a need to reflect more explicitly on issues of language, which are in many cases, but not necessarily, nationally bound, including specificities of concepts and contexts. In the following section I will therefore reflect on methodological implications of potential conceptual and contextual misfits that are connected to these distinct language spheres, which come to the foreground as soon as translation is concerned on a very practical level.

\section{Methodological concerns of language and translation}

Similar to issues of language and power, translation is not necessarily seen as an issue of methodological concern. In its classical sense, 'translation... is the replacement of text in a source language by text in a target language equivalent in meaning' (Müller, 2007: 207). Conceived in this way, the act of translation appears as a technical process. Yet, as Müller outlines, the 'full' equivalence of meaning can never be achieved; it remains partial and can never be total (see also Catford 1965). There are a variety of suggestions in support of this claim such as the idea that languages structure the world in different ways (Müller, 2007). Following Deleuze and Guattari (1987), one may see some languages more as root languages based on, for example, the German thinking of 'either/or' and others as rhizomatic languages such as English, which to Helms et al. (2005) seem to operate more on the basis of 'and, and, and...'. Next to these difficult questions of how different languages may influence the way we think about the world, which go beyond the scope of this essay, there are some other, more practical questions as to why equivalence in meaning remains partial, but is nevertheless useful to be reflected upon.

There is, for instance, the inability to transfer the richness of connotations (Müller, 2007). This is the case for seemingly banal and everyday words such as bread: Brot means something different to a German from pain to a French person (Benjamin 1970: 75) - and bread to someone from the UK. Even if two words in different languages 'intend' the same object, they do not have what Benjamin calls the same 'modes of intention'. Temple's example of conceptual and context dependent differences of the meaning of 'family' illustrate this further:

The concept "family"... is easy to translate literally into Polish (rodzina). It is then easy to assume that when discussing 'the family' in Poland, we are talking about the same concept as 'the family' in England or "rodzina" in England. As recent debate in the West indicates, the concept can be defined in many ways (Temple 1994) with what is being referred to changing with context (1997: 611).

Similar tendencies account for basic notions of political geography, which may be conceived of differently in different languages as Sidaway et al. demonstrate in 'Translating political geographies' (2004). 'State', 'territory' and 'border' are thought of differently in Portuguese and Spanish, Malay, Korean, Japanese, Urdu or Thai.

Finding equivalence in meaning is especially challenging if the meaning is richer in the target or the source language. Müller uses the examples of several Russian words that all translate as 'power' in English, but that address power in relation to very different contexts: power in the sense of authority, rule and territorial power (vlast'); power as a military force or policing power (sila); and, finally, power in the sense of the state as a power (derzhava) (Müller, 2007: 207-8). Müller shows that translations that are not sensitive to these differences in meaning may be de-politicising. 
With increasing complexity in terms of the notions, the complexity of translation rises. The following example will demonstrate this. In recent years, the notion of 'shrinking cities' [schrumpfende Städte] became a widely used term for cities that lose population in Germany. It is closely related to the unification process of Germany, in which most parts of East Germany underwent economic decline resulting in large-scale migration of people from East to West. At first, city councils resisted talking openly about the decline of their cities, but, with many housing associations protesting because of feared bankruptcy due to empty housing stock, the topic came on the political agenda. It was soon taken up by different kinds of agents and now a rich field of research has developed around this issue. Today, shrinking cities in Germany are not seen as limited to the East any longer.

However, this field of research has not crossed language boundaries. In the UK a similar field of research does not exist even though some cities such as Liverpool share some of the histories of shrinkage. So far, to be a 'shrinking city' is not a way to be for a city in the UK. The Cities Unlimited report of the Conservative think-tank Policy Exchange (Leunig and Swaffield, 2007) may illustrate this. Focusing on similar phenomena such as population loss and indicators of economic development the report announces that despite urban regeneration efforts northern cities are (still) lagging behind. The conclusion this report comes to is to make space for three million new homes in the southern growth poles of Cambridge, Oxford and London in order to help people to relocate to areas where they would have better prospects of finding a job. In the public debate, this report was met with complete rejection (see Drury, 2008; Watt, 2008; Morris, 2008).

Using this example, I do not want to suggest that it is important to what extent the empirical contexts in the UK and Germany are different and therefore 'produce' different conceptual research. There certainly is difference, but even though some of the phenomena like loss of population are shared by cities in different language contexts, the 'shrinking city' way of seeing the world represents a German specificity, which in itself does not reflect a homogenous field of research. Nevertheless, framing cities as 'shrinking' puts certain aspects of lack and loss centre stage, which are otherwise glossed over. Finally, in breaking with growth as the main development trajectory the shrinking cities concept bears some political potential even though it may not always work as such in practice.

In clearly situating such conceptual and contextual specificities the contingency of their existence is revealed. The world could look different in Germany, but also in the UK. This is an important contribution that can be made by research that transgresses such worlds, which are not necessarily, but in some cases 'contained' by languages. And it goes to the heart of how knowledge is produced. Ultimately it raises issues of the extent to which one can generalise from one context to the other. Language is in this respect just one of the boundaries that can be transgressed and the way this can be done is by critically translating, which extends to much more contextual and conceptual work than one may have anticipated. In rendering explicit the conceptual and contextual specificities and differences this work goes beyond conventional translation. In this context, Müller calls for a critical translation practice:

[C]onventional translation is... deeply de-politicizing: it glosses over the political act of exclusion involved in any kind of translation... uncritical translation naturalizes the translated text as an objectivity which came into being in the course of a seemingly unpolitical act...In order to achieve a translation mindful of its political and hegemonizing effects, researchers must tease out the political element in their translations. The aim of critical translation in this sense would not be to fashion "better" translations through achieving a higher degree of 
equivalence but rather to destabilize and denaturalize the hegemony of the translated text (2007: 208-9).

In turn, critical translation, I will argue, provides the opportunity to be 'politicizing' where conventional translation is 'de-politicizing'. I will show this using another example from my area of study. Plattenbau can be translated as 'prefabricated concrete slab building', yet, it refers specifically to the industrialised and standardised building types of the GDR and subsequently in many cases to areas built solely of this building type. Even though similar kinds of buildings were constructed in West Germany, France, Sweden and other parts of Europe they are never referred to as Plattenbau or Platte; they do not even have their own name. Plattenbau thus is more than a style of construction. As a notion it carries a whole range of connotations. During GDR times, Plattenbau and Plattenbau areas were seen as an important component in producing socialist citizens, whereas after German Unity this building type and its areas turned into one of the symbols of failure of the GDR urban policies (see Hannemann, 2005; Richter, 2006). To simply translate Plattenbau with 'industrialised building type of the GDR' or similar half sentences captures but a fragment of the politically charged content of this notion. However, in providing more contextual information the political implications and connotations of this notion can be shown.

In this way, translation can be used to make explicit the otherwise implicit political content of a text. The contextual material I provide in the translation offers a different reading from the conventional reading - translating in this manner is to a certain degree a creative act, it literally creates something new in also questioning the source language meaning. Such translation provides an opportunity to render the interpretation process more visible and can also lead to new ideas about one's own language: "Hybrid spaces of research between "home" language and the "foreign" language can open new spaces of insight, of meaning which dis-place, de-centre the researcher's assumption that their own language is clear in its own meaning' (Smith, 1996: 163).

There are some practical considerations for the writing process which can serve to support the reflections of this section. Most importantly, this concerns the visibility of the source language in the target language text. Müller (2007) suggests making the reader 'trip' over in the translated text, in using the original foreign language notions in the text and in making the translation process visible where necessary. This can provide useful insights not only for the reader, but also for the researcher. The opportunity these reflections offer is to raise awareness of both the foreigner and the English native speakers of the issues that are connected to language.

\section{Conclusion: translation as a productive research practice}

Having examined both broad fields of language and power and language and translation, I have advocated a critical approach to translation that pays more attention to concepts and contexts than conventional translation (Smith, 1996; Müller, 2007). Discussing the debate around language and power, which centres on publication practices in so-called 'international' (English language) journals and access of nonnative speakers to these, I have drawn attention to two issues that have methodological implications: the perceived hierarchy of languages and different scholarly traditions. I suggested that a reflective research practice, similar to feminist and post-colonial approaches, may help to address the first issue. In order to deal with the second issue I referred to the inherently hybrid character of social science research in general and geographical and planning research in particular. Here, certain 
concepts, which originated from a foreign language context, but became common currency in the English language context, served to illustrate how the imagination of distinct national spheres of theorisation misses out on the more complex issues of the production of knowledge. However, this does not make reflections on translation obsolete, as some differences between scholarly traditions remain according to respective language contexts. These are discussed in greater detail in the following part of the article. Amongst others, two examples drawn from my own research, the concept of 'shrinking cities' and the notion Plattenbau serve to illustrate how critical translation provides the opportunity to draw out the political implications of the concepts used in research. Translation in this sense, I argue, can become a productive process, where languages can no longer be seen as opponents, such as in asserting the differences between different scholarly traditions, but merely as vehicles. Smith captures this neatly: "[A]s a writing strategy [a focus on translation] demands that differences, tensions and conflicts are explored, not as problems, but as spaces of conceptual and indeed political opportunities and negotiations' (1996: 165). Finally, seeing translation as a productive, creative and open-ended process that is kept visible, may also have wider consequences. In opening up the English language to more debate about the stability of its meanings and to confront it with other languages in all their contextual and conceptual richness may provide a step towards undermining Anglophone hegemony, which is to a large extent based on practices of exclusion of different scholarly traditions and scholars alike. It is at this point that the seemingly distinct discussions of language and power and language and translation that I have identified at the outset intersect. In this way, English may gradually become 'a vehicle to preserve geographical diversity' (Rodríguez-Pose, 2004) instead of silencing other geographical traditions as suggested by the literature on Anglophone hegemony.

\section{Acknowledgements}

Many thanks to Margo Huxley and two anonymous referees for comments and advice on an earlier draft of the paper. Next to this, a big thank you to Richard Wood for proof reading the final version. The responsibility for the content and any errors and omissions in the resulting work remains my own.

* Correspondence Address: Nina Gribat, Sheffield Hallam University, Howard Street, Sheffield, S1 1WB. Email: n.gribat@shu.ac.uk.

\section{References}

Aalbers, M.B. (2004) Creative destruction through the Anglo-American hegemony: a non-Anglo-American view on publications, referees and language. Area, 36, 3, 319-22.

BBC News (2008) Rise of foreign students in UK. http://newsvote.bbc.co.uk/mpapps/pagetools/print/news.bbc.co.uk/2/hi/uk_ne ws/education/7181806.stm, last accessed 06/04/2009.

Belina, B. (2005) Anglophones: If you Want us to Understand You, You Will Have to Speak Understandably! Antipode, 37, 5, 853-55.

Benjamin, W. (1970) The task of the translator, in: Arendt, H. (ed.) Illuminations. London: Jonathan Cape.

Bialasiewicz, L. and Minca, C. (2005) Old Europe, new Europe: for a geopolitics of translation. Area, 37, 4, 365-72. 
Catford, J.C. (1965) A linguistic theory of translation: an essay in applied linguistics, in: Volume 8 Language and language learning. Oxford: Oxford University Press.

Deleuze, G. and Guattari, F. (1987) A thousand plateaus. Capitalism and schizophrenia. London: Athlone Press.

Desbiens, C. and Ruddick, S. (2006) Speaking of geography: language, power, and the spaces of Anglo-Saxon 'hegemony'. Environment and Planning D: Society and Space, 24, 1-8.

Drury, I. (2008) Abandon poverty-stricken north and make people move to the south, says Tory think-tank. Daily Mail, $13^{\text {th }}$ of August 2008.

Faludi, A. (2004) Territorial Cohesion: Old (French) Wine in New Bottles? Urban

Studies, 41, 7, 1349-65.

Garcia-Ramon, M-D. (2003) Globalization and international geography: the question of languages and scholarly traditions. Progress in Human Geography, 27, 1, 1-5.

Gutierrez, J. and López-Nieva, P. (2001) Are international journals of human geography really international? Progress in Human Geography, 25, 1, 53-69.

Hannemann, C. (2005) Die Platte. Berlin: Verlag Hans Schiller.

Helms, G., Lossau, J. and Oslender, U. (2005) Einfach sprachlos but not simply speechless: language(s), thought and practice in the social sciences. Area, 37, 3, 242-50.

Kitchin, R. (2005) Disrupting and destabilizing Anglo-American and English-language hegemony in geography. Social and Cultural Geography, 6, 1, 1-15.

Kollmorgen, R. (2007) Diskursive Missachtung: Zur Subalternisierung ostdeutscher Soziokulturen. Zeitschrift für das vereinigte Deutschland, 40, 3, 481-96.

Leunig, T. and Swaffield, J. (2007) Cities Unlimited. Making urban regeneration work. London: Policy Exchange.

Mandiyanike, D. (2009) The dilemma of conducting research back in your home country as a returning student - reflections of research fieldwork in Zimbabwe. Area, 41, 1, 64-71.

Minca, C. (2000) Venetian geographical praxis. Environment and Planning D: Society and Space, 18, 285-89.

Morris, N. (2008) Cities in North doomed, says favourite Tory think-tank. The Independent, $13^{\text {th }}$ of August 2008.

Moss, P., Berg, L.D., Desbiens, C. (2002) The Political Economy of Publishing in Geography. ACME, 1, 1, 1-7.

Müller, M. (2007) What's in a word? Problematizing translation between languages. Area, 39, 2, 206-13.

Paasi, A. (2005) Globalisation, academic capitalism, and the uneven geographies of international journal publishing spaces. Environment and Planning A, 37, 76989.

Richter, P. (2006) Der Plattenbau als Krisengebiet: Die architektonische und politische Transformation industriell errichteter Wohngebäude aus der DDR am Beispiel der Stadt Leinefelde. Thesis submitted at: Universität Hamburg, FB Kulturgeschichte und Kulturkunde.

Rodríguez-Pose, A. (2004) On English as a vehicle to preserve geographical diversity. Progress in Human Geography, 28, 1, 1-4.

Rose, G. (1997) Situating knowledges: positionality, reflexivities and other tactics. Progress in Human Geography, 21, 3, 305-20.

Samers, M. and Sidaway, J.D. (2000) Exclusions, inclusions, and occlusions in "AngloAmerican geography': reflections on Minca's "Venetian geographical praxis". Environment and Planning D: Society and Space, 18, 663-6.

Short, J.R., Boniche, A., Kim, Y. and LiLi, P. (2001) Cultural Globalization, Global English, and Geography. Professional Geographer, 53, 1, 1-11.

Sidaway, J.D., Bunnell, T., Grundy-Warr, C., Mohammad, R., Park, B.G. and Saito, A. (2004) Translating political geographies. Political Geography, 23, 1037-49. 
p. 131. Translating productively: texts, contexts and concepts

Smith, F. (1996) Problematising language: limitations and possibilities in 'foreign language' research. Area, 28, 160-66.

Temple, B. (1994) Combining Methods: Epistemological Considerations in the Study of Families and Households. Journal of Family Issues, 15, 562-73.

Temple, B. (1997) Watch Your Tongue: Issues in Translation and Cross-Cultural Research. Sociology, 31, 607-18.

Temple, B. and Young, A. (2004) Qualitative research and translation dilemmas. Qualitative Research, 4, 2, 161-78.

Tönnies, F. (1940) Fundamental Concepts of Sociology. New York, American Book Company.

Watt, N. (2008) Tories' favourite think-tank brands northern cities failures. The Guardian, $13^{\text {th }}$ of August 2008. 